\title{
Kommunikatsioonipuuete märkamine, hindamine ja ületamine
}

\author{
Marika Padrik $^{\mathrm{a}}$ \\ ${ }^{a}$ Tartu Ülikooli haridusteaduste instituut
}

Padrik, M., Hallap, M., Raudik, S., Naestema, R., Oselin, H., Jahu, M., Nursi, A., Koplimäe, J., Raidla, U., Brin, I., Uriko, A., \& Kaasik, B. (2016). Kommunikatsioonipuuded lastel ja täiskasvanutel: märkamine, hindamine ja teraapia. Tartu: Tartu Ülikooli kirjastus.

2016. aasta augustis toimus Eesti logopeedias ajalooline sündmus: ilmus kõrgkooliõpik „Kommunikatsioonipuuded lastel ja täiskasvanutel: märkamine, hindamine ja teraapia“. Õpik valmis Eesti riigi toetatud programmi „Eestikeelsed kõrgkooliõpikud 2013-2017“ raames. Tegemist on mahuka raamatuga (569 lk), mis oma olemuselt on pigem käsiraamat, sisaldades nii aineregistrit, terminiseletusi, viiteid, soovituslikku kirjandust kui ka hulgaliselt jooniseid, juhtumikirjeldusi, näiteid töövõtete ja meetodite kohta. Õpiku toimetajad on Tartu Ülikooli logopeediaõppejõud Marika Padrik ja Merit Hallap. Autorid on nii õppejõud kui ka logopeedid-praktikud.

Logopeediat on Eestis ópetatud alates 1968. aastast. 1973. aastal ilmus esimene eestikeelne käsiraamat „Logopeedia alused“ (toim Tiia Espe), mis tänapäevaks on lootusetult vananenud. Nimelt on logopeedia maailmas, sh Eestis, 43 aasta jooksul väga kiiresti arenenud: paljusid teemasid (nt neelamishäired, müofunktsionaalsed puuded) möödunud sajandi kuuekümnendatel aastatel logopeedias ei käsitletudki või käsitleti teisiti. Märkimisväärselt on muutunud logopeedide kasutatavad hindamisvahendid. Teraapiameetodite puhul on kujunenud oluliseks teadus- ja tõenduspõhisus. Kuna logopeedia on keelespetsiifiline valdkond ning kõne- ja keelepuuded avalduvad keeliti erinevalt, pole võimalik teistest keeltest üle võtta puuete avaldumise kirjeldust, hindamis- ja teraapiavõtteid ega -meetodeid. Hädavajalik on toetuda just eesti keeles tehtud uuringute tulemustele.

Õpikus on esitatud uusim rahvusvaheline teaduspõhine info ning Eestis tehtud teadus- ja rakendusuuringute tulemused ning neid omavahel seostatud. See ülesanne oli ühtaegu keeruline ja huvitav, sest Eesti on ühenduslüli eri 
kultuuriruumide vahel, kus räägitakse samast nähtusest veidi erinevas võtmes ja erinevat terminoloogiat kasutades. Euroopa logopeedia häll on Saksamaa, kus 19. sajandil toimus üleminek meditsiiniliselt sekkumiselt, st ravilt medikamentide või kirurgiliste meetoditega, õpetuslikele meetoditele. Iseseisva teadusharu - kõneravipedagoogika (sks Sprachheilpädagogik) - kujunemine Saksamaal 19. sajandi teisel poolel osutus logopeedia ajaloos murdepunktiks. Euroopas (valdavalt Saksamaal ja Austrias) tehtud uuringud olid aluseks logopeedia arengule 20. sajandi alguspoolel ka Venemaal ja Eestis. Nõukogude ajal kujunes Moskvas välja väga tugev (neuro-)psühholoogiline koolkond (piisab vaid Aleksander Luria ja Lev Võgotski nimetamisest), kes pani kindla aluse noorele rakendusteadusele - eripedagoogikale -, mille toel arenes ka logopeedia. Kui läänemaailm oli nõukogude Venemaa teadustulemustest isoleeritud, siis Eesti (nagu kogu Baltikumi) teadlastel oli neile ideaalne ligipääs. Seega oli 1970.-1980. aastatel õnn ja võimalus ehitada Eesti eripedagoogika ja logopeedia üles parimale Vene psühholoogiateadusele. 21. sajandil on Eesti logopeedia avatud kogu maailma teadusinfole, olles tõenäoliselt rohkem mõjutatud Põhjamaadest. Õpikus ongi püütud sünteesida parimaid koolkondi nii idast kui ka läänest, viia kokku erinev terminoloogia. Seda tehes on autoritel olnud pidevalt silme ees Eesti kultuurikontekst ja haridusmaastik, kus logopeedid toimetavad.

Läbiv põhimõte õpiku koostamisel oli tuua näiteid praktikast, st kirjeldada juhtumeid ja nende arengudünaamikat ning pakkuda praktikas kontrollitud teraapiavõtteid, juhendeid ja metoodikat. Olgu siinkohal rõhutatud, et kõigil õpiku autoritel on hea praktiline töökogemus, mis võimaldas seda teha.

Peale eespool mainitud ida ja lääne teaduskoolkondade sünteesi on autorid õpikusse koondanud ka Eestis tehtud teadus- ja rakendusuuringute tulemused, nt eakohase ja hälbelise kõne- ja keelearengu kirjeldus, spetsiifilise kõnearengupuude, kirjaliku kõne ja häl̈lduspuuete, neurogeensete kommunikatsioonipuuete avaldumine eesti keeles, keelespetsiifika arvestamine logopeedilises hindamises ja kõnearenduses, kogelusteraapia kohandamine ja rakendamine lastel ning noorukitel. Õpiku 13 peatükis käsitletakse kõiki peamisi kõne- ja keelepuudeid ning neelamishäireid.

I peatükis „Logopeedia alused“ (autorid Marika Padrik ja Merit Hallap) määratakse kindlaks raamistik järgnevate peatükkide jaoks. Arutluse alla võetakse kommunikatsiooni tähtsus inimese elus ja selgitatakse, mis kriteeriumide alusel saab otsustada, et tegemist on kommunikatsioonipuudega ning millistel juhtudel pole logopeediline abi vajalik. Näiteks ei peaks logopeed toetama kakskeelse lapse keelelist arengut, v.a juhul, kui sellisel lapsel avaldub keelepuue. Selle äratundmine piiratud keeleoskusega väikelapsel on logopeedidele kogu maailmas paras proovikivi. Põhjalikult peatutakse logopeedi töö põhimõtetel, 
näiteks kommunikatiivsuse põhimõttel, mille kohaselt on logopeedi töö ülim eesmärk tagada inimese kommunikatsioonivõime. Olenemata sellest, kas logopeed töötab kliinikus või lasteaias/koolis, on tema töömeetodid oma olemuselt pedagoogilis-psühholoogilised, st inimest suunatakse ja mõjutatakse ning tema suhtlus- ja arengukeskkonda kujundatakse või kohandatakse, lähtudes seatud teraapiaeesmärkidest. Lühiülevaade logopeedia ajaloost kinnitab eriala kiiret arengut: möödunud sajandi keskpaigast alates töötasid logopeedidena erikursused läbinud õpetajad, seejärel kujunes välja eripedagoogi-logopeedi elukutse, millest on tänapäevaks nii Eestis kui ka mujal maailmas saanud kaks iseseisvat elukutset: eripedagoog ja logopeed.

II peatükis „Logopeediline hindamine“ (autor Marika Padrik) käsitletakse logopeedi tööd kliendi kommunikatsiooniprobleemide lahendamisel, mille puhul on esimeseks sammuks hindamine. Selle protsessi eesmärk ei ole sildistamine (diagnoosimine halvas tähenduses), vaid kliendi kommunikatsiooniprobleemi mõistmine. Seejuures on logopeedide kasutatavad hindamisvahendid aja jooksul märkimisväärselt muutunud. Näiteks on Eestis olemas laste kõne arengu standardiseeritud originaaltestid, logopeedide käsutuses on instrumentaalsed hindamismeetodid neelamis- ja häälepuuete tarbeks. Tänu sellele on hindamine kui üks tähtis osa logopeedi tööst muutunud oluliselt objektiivsemaks.

Järgmises kahes peatükis, mille autor on Signe Raudik, rägigitakse probleemidest, millega puutuvad õpetajad ja lapsevanemad sageli kokku. Häälduspuuete peatükist selgub, et see, mis on normiks soome, inglise või vene keeles, ei ole seda eesti keeles (nt keeletipuhäälikute hääldus on keeliti erinev, kolm väldet on iseloomulikud eesti keelele ning häälikute heliline ja/või palataliseeritud hääldamine inglise ja vene keelele). Vaatlusaluses peatükis soovitatakse eestikeelset kirjandust, mida saab kasutada õige häälduse kujundamisel, kui logopeed on välja selgitanud, mis on häl̈ldusvigade täpne põhjus ja kuidas seda ületada. Seevastu müofunktsionaalsed puuded (IV peatükk) põhjustavad sageli häälduse häirumist, aga ka hambumusprobleeme ning on tihedalt seotud vale hingamisega (st suukaudse hingamisega ninahingamise asemel). See on valdkond, kus logopeedi, ortodondi ja kõrva-nina-kurguarsti tööpõld on tihedalt põimunud.

Häälepuuete peatükis (autor Riin Naestema) käsitletakse probleeme, mida teadvustatakse Eestis lubamatult vähe, kuid mis puudutavad kõigi nn rääkivate elukutsete esindajaid, aga ka lauluharrastajaid - nii lapsi kui ka täiskasvanuid. Näiteks on fonotrauma ehk häälekurdude trauma sagedasim häälepuude põhjus, mis on tingitud hääle väärkasutusest. Liiga palju ja valjult rääkimine või vale häälekasutus viivad selleni, et inimene ei saa tegelda oma erialase tööga või harrastusega, mis omakorda mõjutab teda emotsionaalselt või sotsiaalselt. 
Järjest rohkem patsiente leiab tee logopeedi juurde, kelle käsutuses on mitmed instrumentaalsed hindamisvahendid ning teraapiameetodid, mille tulemusena ei pea kõiki funktsionaalseid häälepuudeid ravima enam kirurgiliselt, mida ajalooliselt on tehtud. Tegemist on Eesti logopeedias kiiresti areneva valdkonnaga.

Velofarüngeaalfunktsiooni puudulikkusest tingitud kõnepuuete peatükis (autor Marika Padrik) räägitakse puuetest, mille korral kõne on ninakõlaline ehk nasaalne. Põhjusi võib olla seejuures mitmeid alates suulaelõhest ja lõpetades kuulmislangusega. Loomulikult on tähtis mõista puudemehhanismi, sest teraapia valik sõltub ninakõla põhjusest. Inimese elukvaliteedi parandamisel on rõhuasetus meeskonnatööl, milles on oluline roll kirurgil, logopeedil, ortodondil ja kõrvaarstil. Peatükis on toodud näiteid autori logopeedipraktikast, et illustreerida seda, kui erinevalt võib nimetatud puue avalduda ja kuidas logopeedi töö sõltub konkreetsest juhtumist.

Kõnemotoorikapuuete peatükis (autor Merit Hallap) seatakse fookusse kaks ajukahjustuse tagajärjel tekkinud kõnepuuet: düsartria ja kõneapraksia. Kõneliigutuste juhtimine ja/või realiseerimine võivad häiruda nii lastel kui ka täiskasvanutel. Rasketel juhtudel ei saa inimene rääkida või lapse kõne ei arene, samas on säilinud kõne mõistmine ja kirjaliku kõne oskus. Kuna kõnest on väga raske aru saada, kannatab oluliselt suhtlemise kvaliteet. Teraapia kestab aastaid ja eeldab logopeedilt häid teadmisi neuroloogiast, sh liigutuste juhtimisest ajutasandil.

Kõnesujuvuspuuete peatükis (autorid Helena Oselin ja Maret Jahu) võetakse vaatluse alla kogelus, millega on kokku puutunud ilmselt kõik inimesed, ning vähem tuntud puue, mille jaoks uue termini - klatter - võtsid peatüki autorid kasutusele õpikut kirjutades. Mõlema puhul on häiritud kommunikatsioon, kuid kui kogeleja on ise oma probleemist häiritud ning võib suhtlusolukordi koguni vältida, siis klatteri esinemisel on hädas selle inimese suhtluspartnerid - ebaühtlane ja kiire kõnetempo, hääldusvead ja kõnetakistused teevad kõne raskesti mõistetavaks. Töö kogelejatega nõuab logopeedilt häid teadmisi psühholoogiast, vajaduse korral ka vahetut koostööd psühholoogiga. Peatükis on toodud huvitavaid näiteid autorite praktikast.

Järgmises kahes peatükis (autor Marika Padrik) käsitletakse lastel esinevaid arengulisi keelepuudeid. Alakõne peatükis kirjeldatakse laste kõne arengut erineva mehhanismiga keelepuude korral ja selle toetamist etappide kaupa. Selliseid lapsi kohtavad kõik õpetajad nii lasteaias kui ka koolis, mistõttu pakub peatükk olulist infot ka neile kui laste kõnearengukeskkonna kujundajatele. Kui alakõne võib olla tingitud väga erinevatest arenguprobleemidest (nt mistahes astmes tunnetustegevuse mahajäämus, aktiivsus- ja tähelepanuhäire), siis spetsiifilise kõnearengupuude (alaalia) puhul ei leia ükski spetsialist tavaliselt mingit selget põhjust, miks laps rääkima ei hakka või miks keeleline areng kul- 
geb nii, nagu laps õpiks emakeelt kui võõrkeelt. Peatükis kirjeldatakse Laine Veskeri ja Marika Padriku eesti keele baasil tehtud doktoritöödele toetudes puude avaldumist ja rakendatavat teraapiat. Selle puude korral võrreldakse logopeedi tööd majaehitusega: lapse keelesüsteem tuleb üles ehitada vundamendist katuseni, kusjuures logopeed on tähtsaim spetsialist lapse abistamisel.

Peatükis „Afaasia ja neurogeensed kommunikatsioonipuuded“ (autorid Aaro Nursi, Jaana Koplimäe ja Marika Padrik) räägitakse afaasiast ehk ajukahjustuse tagajärjel omandatud keelepuudest ja kognitiiv-kommunikatiivsest puudest ehk sellest, mis juhtub inimese keelesüsteemi ja suhtlemisega dementsuse korral. Samuti tuleb juttu keelepuudest traumaatilise ja parema ajupoolkera kahjustuse avaldumisel. Tegemist on neuropsühholoogial põhineva valdkonnaga logopeedias. Kuigi on olemas kindel seos ajukahjustuse koha ja afaasia avaldumise vahel, sõltuvad sümptomaatika ja prognoos konkreetse inimese ajutegevusest, millest annab aimu just kahjustuse avaldumine kõnes ja kognitiivses tegevuses. Seoses eluea pikenemisega on kommunikatsiooniprobleemid tänapäeval sagenenud, mistõttu on vanemaealiste elukvaliteedi säilitamisel ja parandamisel just logopeedil täita oluline roll.

Peatükis „Kuulmislangusega laste kõne“ (autorid Ulvi Raidla ja Inga Brin) antakse põhjalik ülevaade sellest, kuidas eri raskusega ja eri liiki kuulmislangus mõjutab kõne arengut ning tunnetustegevust, kuidas seda tänapäeval kompenseeritakse ja milliste meetodite abil kuulmislangusega laste kõnet kujundatakse. Eraldi vaadeldakse kuulmisimplantaadiga ehk siirikuga laste probleeme. Peatükk on väärt lugemisvara kõigile õpetajatele, kes puutuvad oma töös kokku lastega, kellel on kuulmislangus.

Õpiku viimases peatükis (autorid Anne Uriko ja Birgit Kaasik) käsitletakse neelamishäireid täiskasvanutel ja lastel. Valdkond on kogu maailma logopeedias võrdlemisi uus - Eestis on laste neelamishäiretega tegeldud umbes 30 aastat, kuid tänu diagnostikavõimaluste avardumisele on viimase 10 aasta jooksul laste ja täiskasvanute neelamishäirete teraapias toimunud kiire ja intensiivne areng. Neelamishäire korral võib toidu või vedeliku sattumisel hingamisteedesse tekkida kopsupõletik. Logopeedid tegelevad neelamisega seetõttu, et suures osas samad elundid osalevad ka kõnelemisel ja hääle tekitamisel.

Nii õpiku autorid kui ka kasutajad on ühel meelel, et õpikuga on loodud uus kvaliteet tulevaste logopeedide õppes Eestis. Uus logopeediaõpik võimaldab õppejõududel kasutada aktiivõppe vorme ning üliõpilastel varasemast tunduvalt rohkem arutleda, räkida juhtumikirjeldustest, koostada teraapiaplaane ja hindamiskavasid. Tänu sellele on õppimine muutunud palju rakenduslikumaks.

Kommunikatsiooniprobleeme käsitleva õpiku sihtrühm on eelkõige logopeediatudengid, aga kasulikku infot saavad sellest ka töötavad logopeedid, eripedagoogid, õpetajad, logopeediaga haakuvate meditsiinivaldkondade 
spetsialistid (nt neuroloogid, psühhiaatrid, otorinolarüngoloogid, stomatoloogid) ja lapsevanemad, kel on mure lapse kõne pärast. Õpetajat ei pea huvitama teraapia (see on logopeedi töö), küll aga võiks ta teada, millised kõneprobleemid võivad õpilasel/lapsel esineda ning kuidas need võivad õppimist/arengut mõjutada. Huviline õpetaja võib lugedes ära tunda nii mõnegi oma õpilase või lapse probleemi ning leida mõtteid ja võtteid, kuidas last aidata. Kindlasti võimaldab see lugemisvara paremini mõista logopeedi töö sisu, soodustades õpetaja ja logopeedi koostööd. 